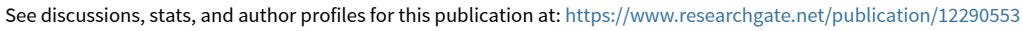

\title{
Tyramine injections reduce locust viability
}

Article in Acta Biologica Hungarica · February 2000

Source: PubMed

\section{6 authors, including:}

43 PUBLICATIONS 1,316 CITATIONS

SEE PROFILE

Arnold De Loof
KU Leuven
$\mathbf{4 4 8}$ PUBLICATIONS 11,848 CITATIONS
SEE PROFILE

Jozef J.M. Vanden Broeck

KU Leuven

280 PUBLICATIONS 5,388 CITATIONS

SEE PROFILE

Some of the authors of this publication are also working on these related projects:

Project Insect gut protease inhibitor adaptation View project

Project PhD project of Johan Geysen View project 


\title{
TYRAMINE INJECTIONS REDUCE LOCUST VIABILITY ${ }^{+}$
}

\author{
H. Torfs, Wendy Van Poyer, J. Poels, Elfriede Swinnen, A. De Loof \\ and J. VANDEN BROECK* \\ Department of Biology, Laboratory for Developmental Physiology and Molecular Biology, \\ K.U. Leuven, Zoological Institute, Naamsestraat 59, B-3000 Leuven, Belgium
}

(Received: August 31, 1999; accepted: November 30, 1999)

In the locust nervous system, tyramine is the direct precursor for octopamine synthesis and, as an octopamine analogue, it can activate octopamine receptors. Furthermore, the identification of specific tyramine receptors in Locusta migratoria and Drosophila melanogaster suggests that it is an important transmitter or modulator candidate. In this paper, we report that repeated tyramine injections reduced the viability of last instar larvae of Locusta and Schistocerca. In addition, a retardation of the last ecdysis was observed as a sublethal effect of the repeated tyramine treatment. Moreover, egg deposition by adult females was also retarded and/or drastically reduced. These effects show similarity to sublethal effects described for certain "insecticidal" octopamine receptor agonists, such as formamidines and phenyliminoimidazolidines. Since certain formamidine compounds were also shown to be agonists for the cloned tyramine receptors, it cannot be excluded that some lethal or sublethal consequences of tyramine administration are the result of an interaction with specific tyramine receptors.

Keywords: Amines - formamidines - octopamine - tyramine - G protein-coupled receptors.

\section{INTRODUCTION}

Monophenolic amines such as octopamine and tyramine are present in the insect CNS. Tyramine (TA) is derived from the amino acid tyrosine via the action of a tyrosine decarboxylase enzyme, whereas octopamine $(\mathrm{OA})$ is produced by hydroxylation of TA. Several effects of TA are reported, but, from these studies, it is not entirely clear whether TA acts as an OA-mimic or whether it exerts these activities as a natural, endogenous messenger molecule $[5,14]$. Recent studies have indicated that a specific TA-uptake system is present in the locust nervous system [6]. The distribution patterns of OA and of TA show some important differences and there are specific, but distinct, binding sites for $\left[{ }^{3} \mathrm{H}\right]$-OA and $\left[{ }^{3} \mathrm{H}\right]$-TA [9]. Moreover, $\alpha_{2}$-adrenore-

\footnotetext{
+ Presented at the 9th ISIN Symposium on "Neurobiology of Invertebrates", July 1-5, 1999, Tihany, Hungary.

*Corresponding author, E-mail: Jozef.VandenBroeck@bio.kuleuven.ac.be
} 
ceptor-like phenolamine receptors which display a much higher affinity for TA than for any other endogenous amine (e.g. OA or dopamine) were cloned from Drosophila melanogaster and from Locusta migratoria [1, 13, 16, 19]. These receptors are pharmacologically distinct from the OA-receptor subtypes that have been described in insect tissues $[7,18,20]$. The fruitfly TA-receptor, when expressed in cultured mammalian cells, shows high affinities towards the insecticidal formamidine compounds demethyl-chlordimeform and amitraz [8]. Therefore, in addition to OA-receptors, TA-receptors may be target sites for certain formamidines. Yohimbine (Yoh), an $\alpha_{2}$ antagonist, possesses a high affinity for the cloned TA-receptors [16, 20]. It is a relatively good antagonist for locust $\mathrm{OA}_{1}$-mediated effects in the extensor tibiae muscle preparation and a very weak antagonist for $\mathrm{OA}_{2}$-mediated effects $[7,14]$.

In order to investigate the effects of TA, we performed a number of simple injection experiments and monitored the viability of last instar larvae and adult locusts.

\section{MATERIALS AND METHODS}

\section{Insect breeding}

Locusts (Locusta migratoria and Schistocerca gregaria) were kept under stable humidity and temperature $\left(30^{\circ} \mathrm{C}\right)$ conditions. Artificial light sources were used to mimic a constant day/night rhythm with $13 \mathrm{~h}$ of daylight. The animals were fed with fresh or frozen grasses and rolled oats. In addition, the desert locusts (Schistocerca gregaria) were fed with fresh cabbage leafs. The two species were kept in separate rooms and they did not leave the gregarious phase.

\section{Injection experiments}

Control and experimental animals were derived from the same synchronized breed: all locusts (Locusta or Schistocerca) used in a single experiment had the same age. Each control or experimental group (of at least ten insects) contained equal numbers of males and females and all animals were treated in a very similar way. Experimental animals were injected by using a graded Hamilton syringe with a diluted solution of one of the following substances (purchased from Sigma) dissolved in PBS (phosphate buffered saline) at different concentrations: p-tyramine (TA), $(+/-)$ octopamine (OA), yohimbine (Yoh), a mixture of p-tyramine and yohimbine (TA/Yoh) or a mixture of ( $+/-$ ) octopamine and yohimbine $(\mathrm{OA} / \mathrm{Yoh})$. Control animals were injected with PBS. All injections were repeated with an interval of one day. The last instar larvae, adults (after the last ecdysis) and dead insects were counted daily in each group of animals. The results were visualized by using the SLIDE or CORRELCHART computer programmes. 


\section{RESULTS}

The result of several independent injection experiments is displayed in Fig. 1. We can summarize the observed effects as follows:

(1) The control animals injected with PBS did not significantly differ from the noninjected animals in the main cage. The moment at which the last ecdysis took place was identical. In addition, these control animals remained healthy and extremely small numbers of dead animals were obtained even after multiple repeats of the injections.

(2) In some experimental groups, the viability of the animals was severely affected. Repeated injections with $4 \mu \mathrm{l}$ of TA at concentrations above $10^{-4} \mathrm{M}$ (which is the TA concentration in the injected solution and not the resulting TA-titre in the insect's haemolymph) clearly had an insecticidal effect. This lethal effect was usually not immediate. It occurred after several daily injections. In sublethal conditions, the moment at which the last ecdysis took place was retarded. Although the effect of tyramine injections was stronger, similar effects were also observed when octopamine was injected.

(3) Interestingly, co-injection of yohimbine together with tyramine or octopamine clearly antagonized these lethal or sublethal effects, whereas injection with yohimbine alone had only a slight effect on locust viability. The observation indicates that yohimbine blocked the deleterious effects of (repeated) tyramine and/or octopamine injections.

\section{$\%$ survival of injected locusts}

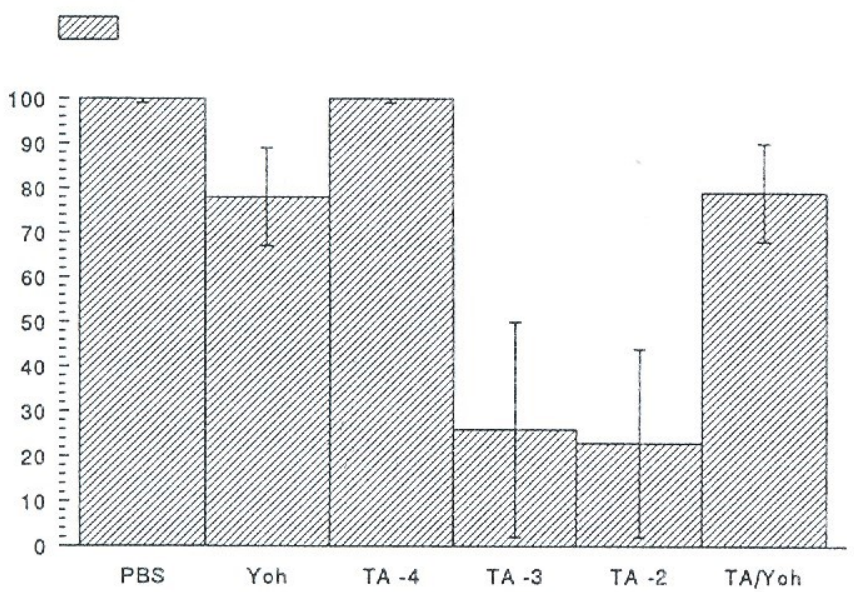

Fig. 1. Histogram showing the percentages of surviving animals (Schistocerca gregaria) obtained from injection experiments with Schistocerca gregaria last instar larvae. Injected solutions contained $4 \mu \mathrm{l}$ of PBS (PBS), $4 \mu \mathrm{l}$ of a $0.1 \mathrm{mM}$ yohimbine solution (Yoh), $4 \mu \mathrm{l}$ of a $0.1,1$ and $10 \mathrm{mM}$ TA solution (TA-4,

TA-3, TA-2) or $6 \mu \mathrm{l}$ of a TA/Yoh mixture $(4 \mu \mathrm{l} 1 \mathrm{mM} \mathrm{TA}+2 \mu \mathrm{l} 0.1 \mathrm{mM} \mathrm{Yoh})$ 
(4) Repeated injections of adult locusts with tyramine (and to a lesser extent with octopamine) appeared to retard the moment of egg deposition. This was shown by comparing several experimental (injections with TA or OA) and control groups (injections with TA or OA in combination with yohimbine) of adult locusts. In an experiment with Schistocerca, the TA-treated animals showed a delay of 2-3 days for egg deposition and for subsequent larval hatching. In a similar experiment with Locusta, the TA-injected animals deposited no eggs during the time of the experiment. A delay of about 5 days was observed for the OAinjected group compared to the TA/Yoh or OA/Yoh groups. Again, yohimbine antagonized the effects of TA and of OA.

\section{DISCUSSION}

Many physiological effects of OA as well as the pharmacology of OA binding sites have been intensely studied in locusts. Compounds such as formamidines and phenylimino-imidazolidines, which are thought to interact as agonists with OAreceptors, or cocaine, which probably affects the octopaminergic system, possess an insecticidal activity [3, 12]. Sublethal effects of these compounds have been described and include many behavioural effects related to crucial physiological processes of insects: hatching and eclosion, control of locomotion, the "arousal syndrome", egg deposition, phototaxis and learning, growth delay and developmental retardation, etc. $[2,3,4,11]$.

The effects observed after injection of TA (and of OA) appear to be very similar to the ones that are elicited by formamidine insecticides. Since the pharmacodynamics of TA administration into the haemolymph are not fully understood, there are some unknown elements: (1) the true concentration of TA (or OA) present in the haemolymph before and after the injections and the effect of inactivation and/or uptake mechanisms for TA (or OA) $[6,10,15,17]$; (2) the accessibility of the possible target sites and the role of the existing blood-brain barrier; (3) the effect of repeated injections on octopaminergic and/or tyraminergic systems, on feedback and desensitization mechanisms. Therefore, it is quite difficult to speculate about the physiological mechanisms that are responsible for the observed effects. The repeatedly injected TA (and OA) has probably mimicked the effect of formamidines in a direct or indirect way. Specific receptor targets could have mediated the lethal and sublethal effects of TA (or OA). Alternatively, TA may have induced (additional) changes to the octopaminergic or tyraminergic systems. The idea that specific receptors might be involved, is supported by the observation that the effects of TA appeared to be stronger than these of OA and by the remarkable fact that yohimbine was a very good antagonist for these effects. Cloned TA receptors from fruitfly and locust display a high affinity for yohimbine and have a much higher affinity for TA than for OA. Furthermore, it was reported that TA-receptors indeed represent potential target sites for certain formamidine compounds [8]. 
Our results form a basis for further studies on the role(s) of phenolamines in insects. The elucidation of the specific functions of OA and of TA will probably depend on the characterization and localization of the pharmacologically distinct receptor subtypes that are involved in mediating the cellular responses to these amines [18]. This will most probably enrich our understanding of the complicated aminergic systems in insects and of the mode of action of certain insecticidal compounds.

\section{ACKNOWLEDGEMENTS}

The authors especially thank T. Janssen, Julie Puttemans and Marijke Christiaens for technical assistance and for help with preparation of the figure, Maria Van der Eeken for help with typesetting of the manuscript and Steve Kotanen for English text correction. R. Jonckers is gratefully acknowledged for insect breeding. Research was supported by the E.U. (BIO4-CT96-0699) and by the Belgian "Interuniversity Poles of Attraction Programme" (IUAP/PAI-IV P4/30, Belgian State, Prime Minister's Office - Federal Office for Scientific, Technical and Cultural Affairs). J.Vd.B. is a Senior Research Associate of the FWOFlanders and W.V.P. and J.P. obtained a PhD. fellowship from the IWT-Flanders.

\section{REFERENCES}

1. Arakawa, S., Gocayne, J. D., McCombie, W. R., Urquhart, D. A., Hall, L. M., Fraser, C. M., Venter, J. C. (1990) Cloning, localization, and permanent expression of a Drosophila octopamine receptor. Neuron 2, 343-354.

2. Cascino, P., Nectoux, M., Guiraud, G., Bounias, M. (1989) The formamidine amitraz as a hyperglycemic alpha-agonist in worker honeybees (Apis mellifera mellifera L.) in vivo. Biomed. Environ. Sci. 2, 106-114.

3. Coats, J. R. (1982) Insecticide Mode of Action. Academic Press, New York, London.

4. Corbet, S. A. (1991) A fresh look at the arousal syndrome of insects. Adv. Insect Physiol. 23, 81-116.

5. Downer, R. G. H., Hiripi, L. (1994) Biogenic amines in insects. In: Borkovec, A. B., Loeb, M. J. (eds) Insect Neurochemistry and Neurophysiology 1993. CRC Press Inc., Boca Raton, pp. 23-38.

6. Downer, R. G. H., Hiripi, L., Juhos, S. (1993) Characterization of the tyraminergic system in the central nervous system of the locust, Locusta migratoria migratoides. Neurochem. Res. 18, 1245-1248.

7. Evans, P. D., Robb, S. (1993) Octopamine receptor subtypes and their modes of action. Neurochem. Res. 18, 869-874.

8. Hall, L. M., Hannan, F., Feng, G., Eberl, D. F., Kousky, C. (1994) Cloning and molecular analysis of G-protein coupled receptors in insects. In: Borkovec, A. B., Loeb, M. J. (eds) Insect Neurochemistry and Neurophysiology 1993. CRC Press Inc., Boca Raton, pp. 53-71.

9. Hiripi, L., Juhos, S., Downer, R. G. H. (1994) Characterization of tyramine and octopamine receptors in the insect (Locusta migratoria migratorioides) brain. Brain Research 633, 119-126.

10. Linn, C. E. Jr., Poole, K. R., Roelofs, W. L. (1994) Studies on biogenic amines and metabolites in the nervous tissue and hemolymph of male cabbage looper moths. III. Fate of injected octopamine, 5hydroxytryptamine and dopamine. Comp. Biochem. Physiol. 108C, 99-106.

11. M'Diaye, K., Bounias, M. (1991) Sublethal effects of the formamidine amitraz on honeybee gut lipids, following in vivo injections. Biomed. Environ. Sci. 4, 376-383.

12. Nathanson, J. A., Hunnicutt, E. J., Kantham, L., Scavone, C. (1993) Cocaine as a naturally occurring insecticide. Proc. Nat. Acad. Sci. USA 90, 9645-9648.

13. Robb, S., Cheek, T. R., Hannan, F. L., Reale, V., Hall, L., Midgley, J. M., Evans, P. D. (1994) Agonistspecific coupling of a cloned Drosophila octopamine/tyramine receptor to multiple second messen- 
gers. In: Borkovec, A. B., Loeb, M. J. (eds) Insect Neurochemistry and Neurophysiology 1993. CRC Press Inc., Boca Raton, pp. 351-354.

14. Roeder, T. (1994) Mini Review. Biogenic amines and their receptors in insects. Comp. Biochem. Physiol. 107C, 1-12.

15. Roeder, T., Gewecke, M. (1989) Octopamine uptake systems in thoracic ganglia and leg muscles of Locusta migratoria. Comp. Biochem. Physiol. 94C, 143-147.

16. Saudou, F., Amlaiky, N., Plassat, J.-L., Borrelli, E., Hen, R. (1990) Cloning and characterization of a Drosophila tyramine receptor. EMBO Journal 9, 3611-3617.

17. Shampengtong, L., Wong, K. P., Ho, B. C. (1987) N-acetylation of dopamine and tyramine by mosquito pupae (Aedes togoi). Insect Biochem. 17, 111-116.

18. Vanden Broeck, J. (1996) G protein-coupled receptors in insect cells. Int. Rev. Cytol. 164, 189-268.

19. Vanden Broeck, J., Verhaert, P., De Loof, A. (1994) Cloning, sequencing and tissue distribution of a putative locust G protein-coupled receptor. In: Borkovec, A. B., Loeb, M. J. (eds) Insect Neurochemistry and Neurophysiology 1993. CRC Press Inc., Boca Raton, pp. 367-370.

20. Vanden Broeck, J., Vulsteke, V., Huybrechts, R., De Loof, A. (1995) Characterization of a cloned locust tyramine receptor cDNA by functional expression in permanently transformed Drosophila $\mathrm{S} 2$ cells. J. Neurochem. 64, 2387-2395. 